\title{
Education
}

\section{Knowledge of university students regarding the use of toxic substances, daily and eating habits with carcinogenic character}

\author{
Conhecimento de estudantes universitários quanto ao uso de \\ substâncias tóxicas, hábitos cotidianos e alimentares com caráter
}

cancerígeno

\section{Raphael da Silva Costa' ${ }^{(D}$, Alexandre Azenha Alves de Rezende' ${ }^{\mathbb{D}}$, Luciana Karen Calábria'i(i) \\ ' Universidade Federal de Uberlândia, Campus Pontal, Ituiutaba, Minas Gerais, Brazil}

\begin{abstract}
The knowledge of university students regarding the use of toxic substances, daily and eating habits with a carcinogenic character was assessed by using a semi-structured questionnaire. In addition, a systematic review was carried out on an electronic basis on the subject. The results revealed that university students know little about the risks and association of high consumption of hyperglycemic foods, omega- 6 and red meat, as well as the exposure to BPA and insecticides, despite the fact that most are aware of the harmful effects of excessive use of cell phones and its relation with cancer. Thus, we notice the importance of disseminating preventive information that promotes a change in living and eating habits with carcinogenic character, resulting in self-care and a better quality of life.
\end{abstract}

Keywords: industrialized food; balanced diet; cell phone; chemical exposure; carcinogenesis

\section{RESUMO}

O conhecimento de universitários sobre o uso de substâncias tóxicas e os hábitos cotidianos e alimentares com caráter carcinogênico foi avaliado por meio de um questionário semiestruturado. Além disso, uma revisão sistemática foi realizada em bases eletrônicas acerca do tema. Os resultados revelaram que os universitários pouco sabem sobre os riscos e associação do alto consumo de alimentos hiperglicêmico, de ômega- 6 e carne vermelha, bem como da exposição ao BPA e inseticidas, apesar da maioria conhecer os malefícios do uso excessivo do celular e sua relação com o câncer. Percebe-se, assim, a importância da divulgação de informações preventivas que promovam a mudança de hábitos de vida e alimentares com caráter carcinogênico, resultando em autocuidado e melhor qualidade de vida. 
Palavras-chave: alimentos industrializados; alimentação balanceada; telefone celular; exposição química; carcinogênese

\section{INTRODUCTION}

Cancer is a disease characterized by the presence of a malignant tumor with cells that have the ability to disorderly grow, which tend to invade tissues and neighboring organs (INCA, 2020a). It is also an important health problem and one of the biggest causes of morbidity and mortality in the world, affecting millions of people. In 2020, there were 9.9 million deaths of cancer, the equivalent to $16.1 \%$ of deaths globally, being the second leading cause of mortality worldwide (WHO, 2018; WHO, 2020). According to the National Cancer Institute (SANTOS, 2018), the SUS Computer Department (DATASUS, 2019) and the INCA (2019), there were more than 235 thousand deaths of cancer in Brazil in 2019, being estimated 625 thousand new cases in the next year. Prostate cancer in men and breast cancer in women were the ones with the highest incidence.

Carcinogenesis in a multicellular organism can result from either one or a combination of chemical, physical, biologic, and genetic insults to individual cells. Numerous toxic substances present in our environment have played an important role in the development of carcinogenesis, which is characterized by a series of genetic and cellular changes, including oncogene activation, that lead the cell to divide in an uncontrolled manner. This process is divided into three stages: initiation, promotion and progression (INCA, 2020a). The initiation phase occurs with the exposure to carcinogens - or potentially carcinogenic substances - and damage to DNA molecules. In the promotion phase, the so-called tumor promoters or active mitogens induce clonal cell expansion. Finally, in the progression phase, the modified cells develop irreversible changes, culminating in the uncontrolled proliferation of cancer cells (KLAUNIG; WANG, 2018). Depending on the mechanism of action of the chemical substance, three classes of chemical carcinogens can be recognized: 1) direct action or ultimate carcinogens - whose chemical structure 
confers them the capacity to induce cancer without a previous metabolic activation; 2) co-carcinogens - chemical substances that cannot induce cancer when they are administered alone, but can enhance the carcinogenic effect of other substances and 3) procarcinogens - substances that become active after previous metabolic activation (BABA; CÂTOI, 2007).

It is clear that cancers are more frequent nowadays compared to the first decades of the last century, and it is important to examine what has changed in the countries, especially after the Second World War in 1940. There are three crucial factors that have drastically changed our environment: the exacerbated increase of sugar consumption; the transformation of agriculture and animal husbandry, reflecting on our food; and the exposure to multiple chemicals (SERVAN-SCHREIBER, 2009; VERNIA et al., 2021). Among them, the chemical exposure is the most reported in literature, as seen in Peres (2015), Ferguson and Solo-Gabriele (2016), Toledo and Nardocci (2016), Ferguson, Penney and Solo-Gabriele (2017), Perlroth and Castelo-Branco (2017), and Saggioro et al. (2019).

All studies corroborate, stating that organochlorine compounds (e.g. DDT and $\mathrm{BHC}$ ), endocrine disrupters (e.g. bisphenol-A), aromatic amines and chlorinated hydrocarbons (mainly aromatic polycyclics) have a high carcinogenic potential. For example, the misuse of some utensils can bring the possibility of ingestion of undesirable compounds, such as bisphenol-A, as well as the high intake of phosphate-based preservatives that have a carcinogenic character (SERVAN-SCHREIBER, 2009). In food, a diet rich in omega-6 polyunsaturated fatty acids increases the incidence and decreases the latency of neoplasms, while a diet rich in omega-3 fatty acids reduces neoplastic development (CRUZ et al., 2019).

Another non-chemical exposure that is also dangerous is found in the electromagnetic fields of cell phones, which if prolonged and continuous increases considerably the risks of acquiring brain cancer (SERVAN-SCHREIBER, 2009). However, there is still no consensus between exposure to radio frequency waves and cancer (BIELSA-FERNANDÉZ; RODRÍGUEZ-MARTíN, 2018). 
Given the risks and harms of chemical and non-chemical exposure to cancers, the objective of this study is to evaluate the knowledge of university students on the use of toxic substances, as well as daily and eating habits with carcinogenic character.

\section{MATERIAL AND METHODS}

The research had two stages, the first one was the application of an opinion survey questionnaire and the second one was the literature review. The semistructured questionnaire was applied using the Google Forms ${ }^{\circledR}$ online platform, and was answered anonymously in May 2019 by 100 university students ranging from several undergraduate courses at the Federal University of Uberlândia, without age and biological sex restrictions. The opinion survey questionnaire allowed us to gather information that led us to the second stage of the research, the literature review, addressing the following topics: eating foods with a high glycemic index; imbalance in fatty acid levels (omega-3 and -6); high consumption of red meat; toxic substances present in household utensils; preservatives and contaminants in food and exposure to electromagnetic radiation from cell phones.

The data collected by the questionnaires were spreadsheet using Microsoft Office Excel ${ }^{\circledR}$ software and analyzed using descriptive statistics, considering absolute (n) and relative (\%) frequencies.

After analyzing the survey, a review of the specialized literature was carried out between May 2019 and June 2021, consulting the electronic databases CAPES, PubMed, Google Scholar, Scielo and USP Repository, on the theme of cancer, using descriptors such as câncer, carcinogênese, substâncias tóxicas and alimentação, and its English correspondents, as well as the Boolean operator "AND" to compose the search strategy. We found articles, dissertations, theses, books and abstracts of scientific events related to the subject of this study. 
Considering the objective of the research and the methodological conduct, this study was not registered or evaluated by the CEP/CONEP system because it meets items VI and VII of article $1^{\text {st }}$ of resolution $n^{\circ} 510$, of April $7^{\text {th }}, 2016$, which exempts from registration the surveys of research data with the objective of theoretical deepening without identifying the subjects involved, as well as a review of the literature based on scientific texts.

\section{RESULTS AND DISCUSSION}

The results obtained from the questionnaire answered by the university students were gathered in Table 1. It was possible to observe that only $48 \%$ of the respondents stated that they knew about the relationship between the high glycemic index and cell proliferation or the predisposition to cancer, including revealing a high daily consumption of white flour (white bread, pasta, white rice, cakes, refined and sweetened breakfast cereals), followed by sugary beverages, industrialized fruit juices and soft drinks, and of sugars (white or brown, honey, guarana syrup and dextrose), corresponding to $89 \%, 66 \%$ and $60 \%$, respectively.

The excessive intake of refined carbohydrates and especially high dietary energy has the potential to increase the risk of cancer, including breast cancer (MULLIE et al., 2016), raising levels of insulin and insulin-like growth factor-1 (IGF1) (ENGIN, 2017; WU et al., 2021). Even resulting in mitogenic and anti-apoptotic effects, with a promoter effect on the carcinogenesis of various types of cancers (ZIELINSKA et al., 2015). Some cancers, such as prostate and breast cancer are called hormone-dependent, as they depend on androgens for their development and progression. Testosterone, for example, is naturally regulated by SHBG (Sex Hormone Binding Globulin), insulin and IGF-1. Therefore, insulin can increase the risk of these cancers by suppressing SHBG levels (AUGUSTIN et al., 2015).

Regarding the excessive consumption of omega- 6 fatty acids, only $34 \%$ of respondents said they were aware of its relationship with the risk of developing 
cancer. On the other hand, the majority reported daily consumption of vegetable oils (62\%), such as soybean, sunflower and/or canola, and products rich in trans fat, such as stuffed cookies, ready-made pies and chips (54\%). The omega-3 and omega- 6 fatty acids participate in physiological processes in reverse, enabling physiological balance. While omega-3 fatty acids regulate inflammation and cell growth, as well as promote blood flow, omega- 6 fatty acids stimulate inflammation, blood clotting and cell growth (SERVAN-SCHREIBER, 2009).

In addition, diets high in fat are generally low in dietary fiber, a fact that increases the time of intestinal transit, favoring the proliferation of bacteria and consequently the degradation of bile acids, producing potential carcinogenic agents, which have greater interaction with the intestinal mucosa. The main harmful agents are bile salts, metabolites of short chain fatty acids, resulting from the increase in intraluminal pH and which are formed at the end of the metabolism of fats and animal protein, determining changes in the epithelium and culminating, therefore, in the development of cancer (VERNIA et al., 2021).

Table 1 - Knowledge of university students regarding the use of toxic substances, daily and eating habits with carcinogenic character, Ituiutaba, MG, 2019

\begin{tabular}{|c|c|}
\hline Evaluated issues & $\%$ \\
\hline \multicolumn{2}{|l|}{ Consumption of food with a high glycemic index } \\
\hline White flour: white bread, overcooked pasta, white rice, cakes, refined and sweetened breakfast cereals & 89.0 \\
\hline Sugary beverages, industrialized fruit juices and soft drinks & 66.0 \\
\hline Sugar: white or brown, honey, guarana syrup and dextrose & 60.0 \\
\hline Potato, mainly mashed potato (except the potato variety Nicola) & 50.0 \\
\hline Jams and fruits in syrup & 9.0 \\
\hline Relationship between the glycemic index and proliferation of cancer cells & 48.0 \\
\hline \multicolumn{2}{|l|}{ Consumption of food rich in omega- 6 fatty acids } \\
\hline Vegetable oils (soybean, sunflower and/or canola) & 62.0 \\
\hline Stuffed cookies, ready-made pies and chips that contain trans fat & 54.0 \\
\hline Margarine & 46.0 \\
\hline Health risks (cancer) due to excessive consumption of omega- 6 fatty acids & 34.0 \\
\hline \multicolumn{2}{|l|}{ Weekly consumption of red meat } \\
\hline Low (up to three times a week) & 34.0 \\
\hline Regular (at least four times a week) & 30.0 \\
\hline
\end{tabular}


Table 1 - Conclusion

Evaluated issues

\begin{tabular}{|c|c|}
\hline \multicolumn{2}{|l|}{ Weekly consumption of red meat } \\
\hline High (everyday) & 35.0 \\
\hline Relationship between high consumption of red meat and breast cancer & 23.0 \\
\hline \multicolumn{2}{|l|}{ Utensils used incorrectly } \\
\hline Soda and food cans & 42.0 \\
\hline Microwave bow/s & 36.0 \\
\hline Cup & 21.0 \\
\hline Electric kettle & 3.0 \\
\hline Baby bottle & 2.0 \\
\hline Toxic substances released by utensils when heated or in contact with hot food & 44.0 \\
\hline \multicolumn{2}{|l|}{ Frequent consumption of foods preserved in phosphate-based substances } \\
\hline Soft drinks (including sugary and fizzy drinks) & 60.0 \\
\hline Processed sweets & 53.0 \\
\hline Meat or processed products derived from pork (with preservatives) & 47.0 \\
\hline Processed ice cream & 40.0 \\
\hline Ready-made industrialized foods (frozen pizza, frozen fish sticks, etc.) & 37.0 \\
\hline Cheese paste & 13.0 \\
\hline Fruit syrups & 3.0 \\
\hline Knowledge regarding substances such as dioxin, polychlorinated biphenyls and certain pesticides, such as DDT & 13.0 \\
\hline \multicolumn{2}{|l|}{ Preventive measures in the risk of cancer generated by the excessive use of cell phone } \\
\hline Avoid keeping the cell phone close to your body, at night do not leave it less than 2 meters away and prefer airplane mode or switched off & 64.0 \\
\hline Restrict the use to short calls, preferring text messages & 54.0 \\
\hline When using, change the ear side regularly and before bringing the cell phone to your ear, wait for the other person to answer. & 45.0 \\
\hline During calls, keep distance from the cell phone (prefer to use speakerphone or a headset). & 45.0 \\
\hline Knowledge regarding the risks of excessive use of cell phone & 73.0 \\
\hline
\end{tabular}

Source: Authors (2020)

Still, $77 \%$ are unaware of the correlation between high consumption of red meat and increased rates of breast cancer, with prevalence in the frequency of weekly consumption, considered as low (34\%), regular (30\%) and high (35\%). The red meat presents a risk factor for the development of cancer when subjected to high temperatures, resulting in the formation of nitrous components, heterocyclic amines and polycyclic aromatic hydrocarbons that are carcinogenic agents. Nitrous compounds, for example, are alkaline agents that can react with DNA, acting on target tissues, changing their bases and, consequently, initiating carcinogenes is (DEMEYER et al., 2016). Also, the consumption of 120 grams/day of red meat, 
compared to no consumption, indicates the estimated risk between 1.24-1.28, reinforcing the adoption of a balanced diet with low intake of this food (ZANDONAl; SONOBE; SAWADA, 2012).

Furthermore, it is in the process of preparing and cooking meat that the release of carcinogenic factors, including nitrates and nitrites, is estimated to occur. $\mathrm{N}$-nitro compounds and nitrate when transformed into nitrite induce tumor formation, resulting in increased cellular damage and production of free radicals. Nitrite can also be formed in cured meats preserved with sodium nitrate and sausages, as well as by the action of saliva that transforms it into nitrite. Besides that, meat prepared at high temperature may have their proteins denatured and result in the formation of heterocyclic amines, which are chemical carcinogens (CASCELLA et al., 2018).

Worldwide, there is a direct relationship between the frequency of cancers and the consumption of meat, cold cuts and dairy products, and an indirect relationship with the consumption of vegetables and legume, and it is recommended to reduce the consumption of red meat to a maximum of 500 grams per week (INCA, 2020b).

Considering the release of toxic substances, such as bisphenol-A, $56 \%$ of the individuals stated that they did not know its relationship with the heating of utensils used in our daily lives, being the soda and food cans (42\%) and the microwave bowls (36\%) the most wrongly used.

Bisphenol-A (BPA) is a synthetic organic compound widely used in the manufacture of polymers, such as polycarbonates, epoxy resins, in addition to a variety of plastics. Such materials are present in thermal papers, sunglasses, medical and dental materials, as well as food packaging, among others. The bioaccumulative character of BPA can lead to DNA degradation and increased cell proliferation, migration, invasion and apoptosis, resulting in tumor progression (GAO et al., 2015). 
BPA, considered as an endocrine disruptor and xenoestrogen, has a powerful chemical toxicity, being one of the components of polyvinyl chloride (PVC) or hard plastic, generally found in the internal lining of several containers in the kitchen and snack bars. This toxic substance is released when the food is heated, having a carcinogenic effect (HU et al., 2012; PAULOSE et al., 2015; WEl et al., 2016). According to Naidu et al. (2021), human health can suffer harmful damage if exposed to endocrine disruptors, which have the ability to disable and modify functions of the endocrine system of various animals, including humans, affecting growth and reproduction, as well as the evolution of cancer.

Regarding the consumption of foods preserved in phosphate-based substances (calcium phosphate, disodium phosphate, phosphoric acid, sodium triphosphate, etc.), the most frequently mentioned were soft drinks, including sugary and fizzy drinks (60\%), followed by processed sweets (53\%).

Servan-Schreiber (2009) points out studies that reveal greater growth of tumors in animals fed a diet rich in phosphate additives, at levels that correspond to those that humans are exposed to when consuming a western diet with industrialized foods and soft drinks. This raises the hypothesis that the excessive amount of phosphate genetically activates the development of cancers. On the other hand, studies on this matter are still scarce and inconclusive.

The consumption of red meat and large fish, as well as milk derivatives, constitutes $90 \%$ of human exposure to contaminants, including substances such as dioxin, polychlorinated biphenyls and certain pesticides such as atrazine. Based on this, $87 \%$ of respondents said they were unaware of these substances.

Chemical substances such as those used in organochlorine insecticides and industrial by-products (DDT, atrazine, dioxin, hexachlorobenzene and aldrin) are typical persistent and bioaccumulative organic pollutants. Although some of these substances have been removed from the market years ago, they are still detectable in agricultural land and in industrial areas where they were present. It is noteworthy that women during pregnancy can mobilize organochlorine residues 
present in body fat, incorporating them into breast milk (VAN-DEN-BERG et al., 2017). In addition, animal experiments have demonstrated the carcinogenic, teratogenic, immunotoxic and endocrine interfering effect of these residues (JAYARAj; MEGHA; SREEDEV, 2016).

Since visceral fat is the main target of accumulation of most carcinogenic compounds, it is evident that breast, ovaries, prostate, colon and lymphatic system cancers are the types with the highest incidence in the West, since these tissues are formed or surrounded by fat (SERVAN-SCHREIBER, 2009). Besides its fat-soluble characteristic, we must consider that the metabolism by-products of many agrochemicals are often more toxic and carcinogenic than the initial molecule itself and can act in a systemic way.

Another important aspect evaluated in this study was the risk of excessive use of the cell phone. From the total investigated, 73\% declared to know the risks, and the main preventive measures were "avoid keeping the cell phone close to your body; at night do not leave it less than 2 meters away and prefer airplane mode or switched off" (64\%) and "restrict the use to short calls, preferring text messages" (54\%).

Electromagnetic fields were determined by the International Cancer Research Agency (IARC) as group 2B "possible human carcinogens" (IARC, 2002; 2011; LEACH; WELLER; REDMAYNE, 2018) and the increased risk of glioblastoma multiforme was revealed after exposure to this magnetic field and associated with the use of cell phones (HARDELL; CARLBERB, 2015; VORNOLI et al., 2019), as well as the increase in glucose metabolism in the brain after 50-minute exposure (VOLKOW et al., 2011). Despite this, Karipidis (2018) did not obtain significant results that could support the association between cell phone use and brain tumor, although he also does not rule out the possibility of a small risk. This divergence of results reinforces the need of studies in the area and that covers a longer latency period. 


\section{CONCLUSION}

The data collected revealed that the university students investigated know little about the risks and association of high consumption of food with a high glycemic index, excessive intake of omega- 6 and red meat, as well as the exposure to bioaccumulative contaminants, such as BPA and insecticides with carcinogenic effects, despite the fact that most students are aware of the harmful effects of excessive use of cell phone and its relation to cancer.

In addition to the little knowledge diagnosis, it was also possible to identify the high consumption of white flour, sugary beverages, refined sugar and vegetable oils, which can be proved to stimulate the body to carcinogenesis, resulting in mitogenic and anti-apoptotic effects, as well as leading to inflammatory responses. However, the investigated population revealed low (or adequate) consumption of red meat, little misuse of utensils that have BPA and adherence to protective measures for the safe use of cell phones.

Therefore, it is noticed the importance of disseminating preventive information which promotes individual reflection about their living and eating habits that have a carcinogenic character, resulting in self-care and better quality of life.

\section{REFERENCES}

AUGUSTIN LS, KENDALL CW, JENKINS DJ, WILLETT WC, ASTRUP A, BARCLAY AW, BJÖRCK I, BRAND-MILLER JC, BRIGHENTI F, BUYKEN AE, CERIELLO A, LA VECCHIA C, LIVESEY G, LIU S, RICCARDI G, RIZKALLA SW, SIEVENPIPER JL, TRICHOPOULOU A, WOLEVER TM, BAER-SINNOTT S, POLI A. Glycemic index, glycemic load and glycemic response: an International Scientific Consensus Summit from the International Carbohydrate Quality Consortium (ICQC). Nutrition, Metabolism \& Cardiovascular Diseases, v. 25, n. 9, p. 795-815, 2015.

BABA Al, CÂTOI C. Comparative Oncology. Bucharest (RO): The Publishing House of the Romanian Academy, 2007. Chapter 2, Carcinogenesis. Available from https://www.ncbi.nlm.nih.gov/books/NBK9552/. Acessed in July 2nd, 2021. 
BIELSA-FERNÁNDEZ P, RODRÍGUEZ-MARTíN B. Asociación entre las radiaciones de teléfonos móviles y el riesgo tumoral en personas adultas [Association between radiation from mobile phones and tumour risk in adults]. Gaceta Sanitaria, v. 32, n. 1, p. 81-91, 2018.

CASCELLA M, BIMONTE S, BARBIERI A, DEL VECCHIO V, CALIENDO D, SCHIAVONE V, FUSCO R, GRANATA V, ARRA C, CUOMO A. Dissecting the mechanisms and molecules underlying the potential carcinogenicity of red and processed meat in colorectal cancer (CRC): an overview on the current state of knowledge. Infectious Agents and Cancer, v. 13, N. 3, p. 1-8, 2018.

CRUZ RS, ANDRADE FO, CARIONI VMO, ROSIM MP, MIRANDA MLP, FONTELLES CC, DE OLIVEIRA PV, BARBISAN LF, CASTRO IA, ONG TP. Dietary zinc deficiency or supplementation during gestation increases breast cancer susceptibility in adult female mice offspring following a Jshaped pattern and through distinct mechanisms. Food and Chemical Toxicology, v. 134, n. 110813, p. 1-9, 2019.

DATASUS - Departamento de informática do SUS. Óbitos por ocorrência por Unidade da Federação segundo ano do óbito (2019), considerando o capítulo CID-10: II. Neoplasias (tumores). Available from http://tabnet.datasus.gov.br/cgi/tabcgi.exe?sim/cnv/obt10uf.def. Acessed in June 17th, 2021.

DEMEYER D, MERTENS B, DE SMET S, ULENS M. Mechanisms linking colorectal cancer to the consumption of (processed) red meat: a review. Critical Reviews in Food Science and Nutrition, v. 56, n. 16, p. 2747-2766, 2016.

ENGIN A. Obesity-associated breast cancer: analysis of risk factors. In: ENGIN AB, ENGIN A (Eds.) Obesity and Lipotoxicity. Advances in Experimental Medicine and Biology, 960, p. 571-606, 2017.

FERGUSON A, PENNEY R, SOLO-GABRIELE H. A review of the field on children's exposure to environmental contaminants: a risk assessment approach. International Journal of Environmental Research and Public Health, v. 14, n. 265, p. 1-25, 2017.

FERGUSON A, SOLO-GABRIELE H. Children's exposure to environmental contaminants: an editorial reflection of articles in the IJERPH Special Issue Entitled, "Children's Exposure to Environmental Contaminants". International Journal of Environmental Research and Public Health, v. 13, n. 1117, p. 1-10, 2016.

GAO H, YANG BJ, LI N, FENG LM, SHI XY, ZHAO WH, LIU SJ. Bisphenol A and hormone-associated cancers: current progress and perspectives. Medicine (Baltimore), v. 94, n. 1, p. 1-8, 2015.

HARDELL L, CARLBERG M. Mobile phone and cordless phone use and the risk for glioma analysis of pooled case-control studies in Sweden, 1997-2003 and 2007-2009. Pathophysiology, v. 22, n. 1, p. 1-13, 2015. 
HU WY, SHI GB, HU DP, NELLES JL, PRINS GS. Actions of estrogens and endocrine disrupting chemicals on human prostate stem/progenitor cells and prostate cancer risk. Molecular and Cellular Endocrinology, v. 354, n. 1-2, p. 63-73, 2012.

IARC - International Agency for Research on Cancer. Non-lonizing Radiation, Part 1: Static and extremely low-frequency (ELF) electric and magnetic fields. Lyon: IARC press, v. 80, 445 p., 2002.

IARC - International Agency for Research on Cancer. Non-lonizing Radiation, Part 2: Radiofrequency electromagnetic fields. Lyon: IARC press, v. 102, 481 p., 2011.

INCA - INSTITUTO NACIONAL DE CÂNCER JOSÉ ALENCAR GOMES DA SILVA. Estimativa 2020: incidência de câncer no Brasil. Rio de Janeiro: INCA, 2019. 120p.

INCA - INSTITUTO NACIONAL DE CÂNCER JOSÉ ALENCAR GOMES DA SILVA. ABC do câncer: abordagens básicas para o controle do câncer. 6. ed. rev. atual - Rio de Janeiro: INCA, 2020 a. $112 p$.

INCA - INSTITUTO NACIONAL DE CÂNCER JOSÉ ALENCAR GOMES DA SILVA. Dieta, nutrição, atividade física e câncer: uma perspectiva global: um resumo do terceiro relatório de especialistas com uma perspectiva brasileira. Rio de Janeiro: INCA, 2020b. 140p.

JAYARAJ R, MEGHA P, SREEDEV, P. Organochlorine pesticides, their toxic effects on living organisms and their fate in the environment. Interdisciplinary Toxicology, v. 9, n. 3-4, p. 90$100,2016$.

KARIPIDIS K, EL WOOD M, BENKE G, SANAGOU M, TJONG L, CROFT RJ. Mobile phone use and incidence of brain tumour histological types, grading or anatomical location: a populationbased ecological study. British Medical Journal Open, v. 8, n. 12, p. e024489, 2018.

KLAUNIG JE, WANG Z. Oxidative stress in carcinogenesis. Current Opinion in Toxicology, v. 7, p. 116-121, 2018.

LEACH V, WELLER S, REDMAYNE M. A novel database of bio-effects from non-ionizing radiation. Reviews on Environmental Health, v. 33, n. 3, p. 273-280, 2018.

MULLIE P, KOECHLIN A, BONIOL M, AUTIER P, BOYLE P. Relation between breast cancer and high glycemic index or glycemic load: a meta-analysis of prospective cohort studies. Critical Reviews in Food Science and Nutrition, v. 56, n. 1, p. 152-9, 2016.

NAIDU R, BISWAS B, WILLETT IR, CRIBB J, KUMAR SINGH B, PAUL NATHANAIL C, COULON F, SEMPLE KT, JONES KC, BARCLAY A, AITKEN RJ. Chemical pollution: a growing peril and potential catastrophic risk to humanity. Environment International, v. 156, n. 106616, p. 1-12, 2021.

PAULOSE T, SPERONI L, SONNENSCHEIN C, SOTO AM. Estrogens in the wrong place at the wrong time: fetal BPA exposure and mammary cancer. Reproductive toxicology, v. 54, p. 58-65, 2015. 
PERES LP. Efeitos transformantes do bisfenol-A e medroxiprogesterona em células epiteliais da mama. [Dissertation]. Uberlândia: Universidade Federal de Uberlândia; 2015. 62 p.

PERLROTH NH, CASTELO BRANCO CW. Current knowledge of environmental exposure in children during the sensitive developmental periods. Jornal de Pediatria, v. 93, n. 1, p. 17-27, 2017.

SAGGIORO EM, CHA VES FP, FELIX LC, GOMES G, BILA DM. Endocrine disruptor degradation by

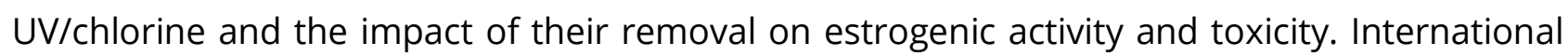
Journal of Photoenergy, v. 2019, p. 1-9, 2019.

SANTOS MO. Estimativa 2018: incidência de câncer no Brasil. Revista Brasileira de Cancerologia, v. 64, n. 1, p. 119-120, 2018.

SERVAN-SCHREIBER D. Anticancer (a new way of life). Paris: Michael Joseph, 2009.

TOLEDO MC, NARDOCCI AC. Avaliação de riscos à saúde humana em área contaminada por substâncias mutagênicas: comparação das abordagens determinística e probabilística. In: Congresso da Sociedade de Análise de Risco Latino Americana, 3, 2016, São Paulo. Available from https://srala.org/wp-content/uploads/2018/08/Memorias 3erCongressoSRALA 2016 SaoPaulocompressed-Alta.pdf. Acessed in July 2nd, 2021.

VAN-DEN-BERG M, KYPKE K, KOTZ A, TRITSCHER A, LEE SY, MAGULOVA K, FIEDLER H, MALISCH R. WHO/UNEP global surveys of PCDDs, PCDFs, PCBs and DDTs in human milk and benefit-risk evaluation of breastfeeding. Archives of Toxicology, v. 91, n. 1, p. 83-96. 2017.

VERNIA F, LONGO S, STEFANELLI G, VISCIDO A, LATELLA G. Dietary factors modulating colorectal carcinogenesis. Nutrients, v. 13, n. 143, p. 1-13, 2021.

VORNOLI A, FALCIONI L, MANDRIOLI D, BUA L, BELPOGGI F. The contribution of in vivo mammalian studies to the knowledge of adverse effects of radiofrequency radiation on human health. International Journal of Environmental Research and Public Health, v. 16, n. 18, p. 1-27, 2019.

VOLKOW ND, TOMASI D, WANG GJ, VASKA P, FOWLERJS, TELANG F, ALEXOFF D, LOGANJ, WONG $C$. Effects of cell phone radiofrequency signal exposure on brain glucose metabolism. The Journal of the American Medical Association, v. 305, n. 8, p. 808-813, 2011.

WEI M, CHEN X, ZHAO Y, CAO B, ZHAO W. Effects of prenatal environmental exposures on the development of endometriosis in female offspring. Reproductive Sciences, v. 23, n. 9, p. 11291138, 2016.

WHO - World Health Organization. Noncommunicable diseases country profiles. Geneva: World Health Organization, 2018. 223p. 
WHO - World Health Organization. Global Cancer Observatory (GCO). 2020. Available from https://gco.iarc.fr/. Acessed in July 2nd, 2021.

WU X, ZHANG X, HAO Y, LI J. Obesity-related protein biomarkers for predicting breast cancer risk: an overview of systematic reviews. Breast Cancer, v. 28, n. 1, p. 25-39, 2021.

ZANDONAI AP, SONOBE HM, SAWADA NO. Os fatores de riscos alimentares para câncer colorretal relacionado ao consumo de carnes. Revista da Escola de Enfermagem da USP, v. 46, n. 1, p. 234-239, 2012.

ZIELINSKA HA, BAHL A, HOLLY JM, PERKS CM. Epithelial-to-mesenchymal transition in breast cancer: a role for insulin-like growth factor I and insulin-like growth factor-binding protein 3? Breast Cancer. Dove Medical Press, v. 7, p. 9-19, 2015.

\section{Authorship contributions}

\section{1 - Raphael da Silva Costa}

Graduated in Biological Sciences

http://orcid.org/0000-0003-1953-294X - dasilvacosta.rafael@gmail.com

Contributions: Formal Analysis, Investigation, Methodology, Visualization, Writing original draft.

\section{2- Alexandre Azenha Alves de Rezende}

PhD in Genetics (Emphasis on Mutagenesis)

http://orcid.org/0000-0003-1751-9194 - azenha@ufu.br

Contributions: Investigation, Visualization, Writing - review \& editing.

\section{3 - Luciana Karen Calábria}

PhD in Biochemistry (Emphasis on Clinical Biochemistry) http://orcid.org/0000-0002-0500-0232 - Ikcalabria@ufu.br Contributions: Formal Analysis, Investigation, Methodology, Resources, Visualization, Writing original draft, Writing review \& editing.

\section{How to quote this article}

COSTA, R. S.; REZENDE, A. A. A.; CALÁBRIA, L. K. Knowledge of university students regarding the use of toxic substances, daily and eating habits with carcinogenic character. Ciência e Natura, Santa Maria, v. 43, e80, p. 1-17, 2021. Available in: https://doi.org/10.5902/2179460X62966. 